\title{
St-PepA, a Streptococcus thermophilus aminopeptidase with high specificity for acidic residues
}

\author{
Francoise Rul, Jean-Claude Gripon and Véronique Monnet \\ Author for correspondence: Francoise Rul. Tel: +331346521 49. Fax: +33134652163. \\ e-mail: rul@jouy.inra.fr
}

Station de Recherches Laitières, Institut National de la Recherche Agronomique, 78352 Jouyen-Josas Cedex, France

\begin{abstract}
The proteolytic system of lactic acid bacteria has been extensively studied over the past 10 years and peptidases from lactococci are now well known. The situation is, however, different for Streptococcus thermophilus from which only a few peptidases have been purified and characterized. The present work was conducted to characterize an aminopeptidase of S. thermophilus CNRZ 302, called St-PepA, with high specificity for acidic amino acids. St-PepA was purified by a three-step procedure from a spheroblast extract of $S$. thermophilus CNRZ 302. Its molecular mass was estimated to be $360 \mathrm{kDa}$ by gel filtration and $45 \mathrm{kDa}$ by SDS-PAGE, indicating that it had an octameric structure. Its activity against aspartate-p-nitroanilide was maximal at pH 8.5 and $62{ }^{\circ} \mathrm{C}$ and highly enhanced by $\mathrm{Zn}^{2+}, \mathrm{Co}^{2+}$ and $\mathrm{Mg}^{2+}$. St-PepA was inhibited by metal-chelating reagents and, to a lesser extent, by agents modifying sulfhydryl groups. It showed an activity towards p-nitroanilide derivatives, diand tripeptides, and larger peptides such as fragment 43-58 of $\alpha_{s 1}$-casein. It had a high substrate specificity towards $\mathbf{N}$-terminal acidic amino acid residues but it could also release serine and malic acid, the $\alpha$-hydroxy acid homologue of aspartic acid. Kinetic studies revealed that the affinity of St-PepA was more than 18-fold higher for aspartic acid-p-nitroanilide $\left(K_{m}=0.42 \mathrm{mM}\right)$ than for glutamic acid-p-nitroanilide $\left(K_{m}=7.65 \mathrm{mM}\right)$ with a similar $V_{\max }$ for both substrates [about $40 \mu \mathrm{mol} \mathrm{min}^{-1}$ (mg enzyme) ${ }^{-1}$ ]. St-PepA is heat stable, with a maximal loss of activity of $15 \%$ after incubation for $120 \mathrm{~min}$ at $50{ }^{\circ} \mathrm{C}$ and $60{ }^{\circ} \mathrm{C}$. It is likely to be involved in the nitrogen metabolism of $\mathrm{S}$. thermophilus and in the development of the organoleptic characteristics of cheese and yoghurt.
\end{abstract}

Keywords: Streptococcus thermophilus, aminopeptidase A, glutamic and aspartic acids, metallopeptidase

\section{INTRODUCTION}

Lactic acid bacteria are widely used as starter cultures in industrial milk fermentations. They require an exogenous nitrogen source for optimal growth (Law \& Kolstad, 1983; Thomas \& Pritchard, 1987). Because milk is relatively poor in free amino acids and small peptides, nitrogen mostly comes from caseins. Thus, the optimal growth of lactic acid bacteria depends on their proteolytic system composed of proteinases and peptidases which can produce these amino acids and small peptides from milk caseins (Kok, 1990; Laan et al., 1989). This proteolytic system is also important because it contributes to the

Abbreviations: $\mathrm{pNa}, \mathrm{p}$-nitroanilide; $\beta$ - $\mathrm{Na}, \beta$-naphthylamide. development of texture and flavour during cheese ripening.

The cell-envelope-associated proteinase and a variety of peptidases with different specificities have been described for the genus Lactococcus (for reviews see Monnet et al., 1993; Tan et al., 1993). Less information is available about the proteolytic enzymes of Streptococcus thermophilus, although it is widely used in the dairy industry. $S$. thermophilus exhibits low levels of proteinase activity and it develops in milk in association with lactobacilli species, the latter producing small peptides which are substrates for peptidases. Several of these peptidases have been described in $S$. thermophilus: a neutral intracellular endopeptidase was purified and characterized from $S$. thermophilus CNRZ 160 (Desmazeaud, 1974). A dipeptidase 
(Rabier \& Desmazeaud, 1973), specific for dipeptides with a large amino acid residue at the $\mathrm{N}$ terminus, and a X-prolyl-dipeptidyl-aminopeptidase (Meyer \& Jordi, 1987) were also described. In addition, two general aminopeptidases similar to those isolated from lactococci were purified from $S$. thermophilus: PepN (Tsakalidou \& Kalantsopoulos, 1992; Midwinter \& Pritchard, 1994; Rul et al., 1994) and PepC, whose gene has recently been cloned (Chapot-Chartier et al., 1994).

As $S$. thermophilus is widely used in the dairy industry in cheese making and yoghurt manufacturing, it is of interest to know more about its peptidasic system. After a screening of aminopeptidase activities, we detected four aminopeptidases in extract of $S$. thermophilus CNRZ 302 spheroblasts. Three are general aminopeptidases (Rul, 1994); the fourth, St-PepA, is an aminopeptidase with high specificity for acidic amino acids. To investigate further the potential role of St-PepA in nitrogen metabolism and organoleptic development of yoghurt and cheese, we purified it and determined its biochemical properties.

\section{METHODS}

Bacterial strain and culture conditions. Streptococcus thermophilus CNRZ 302 was obtained from the collection of the Station de Recherches Laitières (INRA, Jouy-en-Josas, France). It was grown at $37^{\circ} \mathrm{C}$ in $5 \mathrm{l}$ of M17 broth (Difco) containing $5 \mathrm{~g}$ lactose $1^{-1}$. Growth was assessed by measurement of $\mathrm{OD}_{650}$.

Intracellular extract preparation. Cells were collected at the end of the exponential growth phase by centrifugation $(6000 \mathrm{~g}$, $\left.15 \mathrm{~min}, 4^{\circ} \mathrm{C}\right)$. The pellet was washed twice with $50 \mathrm{mM} \beta$ glycerophosphate and then incubated for $2 \mathrm{~h}$ at $30^{\circ} \mathrm{C}$ in $50 \mathrm{mM}$ triethanolamine (TEA) buffer $(\mathrm{pH} 7)$ containing $30 \%(\mathrm{w} / \mathrm{v})$ sucrose, $0 \cdot 1 \mathrm{mg}$ lysozyme $\mathrm{ml}^{-1}$ (Sigma) and $42 \mathrm{U}$ mutanolysin $\mathrm{ml}^{-1}$ (Sigma). The spheroplasts obtained were collected by centrifugation $\left(12000 \mathrm{~g}, 30 \mathrm{~min}, 4^{\circ} \mathrm{C}\right)$ and resuspended in the same buffer without sucrose. After the spheroblasts had burst, the supernatant was recovered by centrifugation $(20000 \mathrm{~g}$, $30 \min , 4^{\circ} \mathrm{C}$ ).

Protein assay. Proteins were determined in the extracts and purified fractions by the method of Bradford (1976) with bovine serum albumin (Pierce) as standard.

Aminopeptidase activity assay. St-PepA activity was assayed against three types of substrates.

Firstly, against amino acid-p-nitroanilides (-pNa) and $-\beta$ naphthylamides $(-\beta-\mathrm{Na})$. The purification of St-PepA was followed by monitoring the release of $p$-nitroaniline from Asp$\mathrm{pNa}$ (Bachem) at $410 \mathrm{~nm}$ as described by Zevaco et al. (1990). In the case of $\beta$ - $\mathrm{Na}$ derivatives, the reaction mixture contained $0.3 \mathrm{mM}$ substrate in $50 \mathrm{mM}$ Tris/ $\mathrm{HCl}(\mathrm{pH} 8)$ in a final volume of $1 \mathrm{ml}$ and incubation was performed at $37^{\circ} \mathrm{C}$. The reaction was stopped by adding $0.5 \mathrm{ml}$ of $1 \mathrm{mg}$ Fast Garnet $\mathrm{ml}^{-1}$. After 25 min incubation at $37^{\circ} \mathrm{C}$, the release of $\beta$-naphthylamine was monitored by measuring $A_{550}$. The unit of activity used was the katal (the quantity of enzyme releasing $1 \mathrm{~mol} p$-nitroaniline or $\beta$ naphthylamine $\mathrm{s}^{-1}$ ).

Secondly, with the purified aminopeptidase, against several di-, tri- and tetrapeptides (Sigma, or Bachem for Asp-Tyr, AspTyr-Met and Asp-Tyr-Met-Gly). Asp-Phe-methyl ester (Asp-
Phe-OMe; Aspartame), Asp-Phe-ethyl ester (Asp-Tyr-OEt) and Mal-Tyr-ethyl ester (Mal-Tyr-OEt; Mal, malyl) were provided by BioEurope. The enzyme fraction was incubated at $37^{\circ} \mathrm{C}$ in the presence of $82 \mu \mathrm{M}$ substrate in $50 \mathrm{mM}$ TEA ( $\mathrm{pH} 8$ ) and $1 \mathrm{mM} \mathrm{CoCl}$. After $1 \mathrm{~h}$ incubation, the reaction was stopped by addition of $10 \% 1 \mathrm{M} \mathrm{HCl}$. The free amino acids present in the hydrolysates of the different peptides were directly identified with a LC3000 amino acid analyser (Biotronik).

Thirdly, against oligopeptides. Angiotensin I and leucokinin were from Sigma. Fragment $43-58$ of bovine $\alpha_{\mathrm{s} 1}$-casein and fragment $115-124$ of caprine $\alpha_{\mathrm{s} 1}$-casein (with free or phosphorylated serine at the $\mathrm{N}$ terminus) were gifts from $\mathrm{G}$. Brignon (INRA, Station de Recherches Laitières, Jouy-enJosas, France). The enzymic reaction was achieved as described above with $1 \mathrm{~h}$ incubation (or $24 \mathrm{~h}$ for the $\alpha_{\mathrm{s} 1}$-casein fragments). The samples were analysed by RP-HPLC using a C18 column in a trifluoroacetic acid (TFA)/acetonitrile solvent system (solvent A, $0 \cdot 115 \%$ TFA ; solvent B, $0 \cdot 1 \%$ TFA, $60 \%$, v/v, acetonitrile). A linear gradient of $20-80 \%$ solvent $B$ was used over 15 min for leucokinin and angiotensin and over $20 \mathrm{~min}$ for fragment 43-58 of bovine $\alpha_{\mathrm{s} 1}$-casein. A linear gradient of $10-50 \%$ solvent $\mathrm{B}$ was used over $30 \mathrm{~min}$ for fragment $115-124$ of caprine $\alpha_{\mathrm{s} 1}$-casein. The peptides collected were then identified with a sequencer (model 477A; Applied Biosystems).

Aminopeptidase purification. Nucleic acids in the cell extract were hydrolysed by adding RNase $(2.75 \mathrm{mg}$ per $100 \mathrm{ml}$ extract; Sigma) and DNase (0.05 mg per $100 \mathrm{ml}$ extract; Sigma) in the presence of $1 \mathrm{mM} \mathrm{MgCl}$. Nucleic acids were then precipitated in the presence of $60 \mathrm{mM} \mathrm{MnSO}_{4}$ and the solution was centrifuged at $10000 \mathrm{~g}$ for $30 \mathrm{~min}$. The extract was then dialysed overnight against $10 \mathrm{mM}$ TEA (pH 7) and filtered through a $0 \cdot 45 \mu \mathrm{m}$ filter (type HVLP, Millipore).

The first ion exchange chromatography was done on a QSepharose Fast Flow XK $26 / 40$ column $(2.6 \times 15 \mathrm{~cm}$; Pharmacia) with a FPLC system. The column was equilibrated with $50 \mathrm{mM}$ TEA ( $\mathrm{pH} \mathrm{7)}$. The extract ( $317 \mathrm{mg}$ protein) was applied to the column and eluted with a linear $\mathrm{NaCl}$ gradient of $0-0.5 \mathrm{M}$ over $5 \mathrm{~h}$ at a flow rate of $5 \mathrm{ml} \mathrm{min}^{-1}$ and $10 \mathrm{ml}$ fractions were collected. Fractions active against Asp-pNa were recovered and dialysed overnight against $10 \mathrm{mM}$ TEA ( $\mathrm{pH} 7 \cdot 5$ ).

The second ion-exchange chromatography was performed by FPLC on a MonoQ HR $10 / 10$ column $(1 \times 10 \mathrm{~cm}$; Pharmacia $)$ equilibrated with $50 \mathrm{mM}$ TEA ( $\mathrm{pH} 7 \cdot 5)$. The proteins were eluted with a linear $\mathrm{NaCl}$ gradient of $0-0.5 \mathrm{M}$ over $4 \mathrm{~h}$ at a flow rate of $3 \mathrm{ml} \mathrm{min}^{-1}$. Three millilitre fractions were collected and the fractions active against Asp-pNa were pooled.

The following hydrophobic interaction chromatography was done with an Alkyl Superose HR5/5 column $(0.5 \times 5 \mathrm{~cm}$; Pharmacia). The column was equilibrated with $50 \mathrm{mM}$ sodium phosphate buffer ( $\mathrm{pH} 7.5)$ containing $1.7 \mathrm{M}\left(\mathrm{NH}_{4}\right)_{2} \mathrm{SO}_{4}$. This was added to the sample which was applied to the column and eluted with a linear gradient of $1 \cdot 7-0 \mathrm{M}\left(\mathrm{NH}_{4}\right)_{2} \mathrm{SO}_{4}$ in $50 \mathrm{mM}$ sodium phosphate ( $\mathrm{pH} 7.5$ ) over $3.5 \mathrm{~h}$ at a flow rate of $0.5 \mathrm{ml} \mathrm{min}^{-1} ; 0.5 \mathrm{ml}$ fractions were collected. Fractions active against Asp-pNa were recovered and dialysed against $10 \mathrm{mM}$ sodium phosphate buffer.

\section{Aminopeptidase characterization}

Electrophoresis. The purified fraction was electrophoresed under denaturing and reducing conditions (SDS-PAGE) using 10\% acrylamide gels (acrylamide/bisacrylamide, 29:1, v/v) according to Laemmli (1970). The proteins were stained with Coomassie Brilliant Blue R-250. The following markers were 
used to determine the molecular mass of St-PepA: myosin $(205 \mathrm{kDa}), \quad \beta$-galactosidase $(116.25 \mathrm{kDa})$, phosphorylase $\mathrm{b}$ $(97.4 \mathrm{kDa})$, bovine serum albumin $(66.2 \mathrm{kDa})$ and ovalbumin $(45 \mathrm{kDa})$. Native electrophoresis (in the absence of SDS and $\beta$ mercaptoethanol) allowed the detection of the aminopeptidase activity under the following incubation conditions: $30 \mathrm{ml} 0.2 \mathrm{M}$ Tris buffer ( $\mathrm{pH} \mathrm{7.5)} \mathrm{containing} 10 \mathrm{mg} \mathrm{Asp-pNa} \mathrm{at} \mathrm{room}$ temperature. Hydrolysis of the substrate was reflected by the appearance of an unstable yellow colour at the level of the enzyme band.

Gel filtration. The molecular mass of St-PepA was estimated by gel filtration on a Superose 12 column (Pharmacia) in $0.15 \mathrm{M}$ $\mathrm{NaCl}, 50 \mathrm{mM}$ TEA $\left(\mathrm{pH} \mathrm{7.5)}\right.$ at a flow rate of $0.25 \mathrm{ml} \mathrm{min}^{-1}$. The column was calibrated with thyroglobulin $(670 \mathrm{kDa}), \gamma$-globulin $(158 \mathrm{kDa})$, ovalbumin $(44 \mathrm{kDa})$, myoglobin $(17 \mathrm{kDa})$ and vitamin B-12 $(1.35 \mathrm{kDa})$.

Effect of $\mathrm{pH}$ on aminopeptidase activity. The effect of $\mathrm{pH}$ on the aminopeptidase activity was determined on Asp-pNa at $37^{\circ} \mathrm{C}$ over a $\mathrm{pH}$ range of $4-10$ using the following $0 \cdot 1 \mathrm{M}$ buffers:

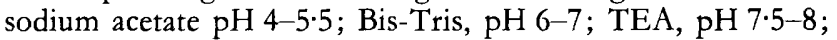
Tris, $\mathrm{pH} 8 \cdot 5-9 \cdot 5$ and CAPS, $\mathrm{pH} 10$.

Effect of temperature on aminopeptidase activity. The effect of temperature on the aminopeptidase activity was determined at temperatures ranging from 20 to $75^{\circ} \mathrm{C}$ with Asp-pNa as a substrate. After incubation of the enzyme at the desired temperature in $50 \mathrm{mM}$ TEA buffer $(\mathrm{pH} 8)$ for $5 \mathrm{~min}$, substrate was added and the reaction mixtures were incubated for $0-20 \mathrm{~min}$ at $20-75^{\circ} \mathrm{C}$. The enzymic activity was then measured as described above.

To determine the thermostability of St-PepA activity, a solution of the purified aminopeptidase in $50 \mathrm{mM}$ TEA buffer ( $\mathrm{pH} 8$ ) containing $1 \mathrm{mM} \mathrm{MgCl}_{2}$, was incubated at $30,40,50$ or $60^{\circ} \mathrm{C}$. After $20,30,60,120$ and $480 \mathrm{~min}$, samples were taken from each incubation mixture and assayed for aminopeptidase activity using Asp-pNa as a substrate described above.

Effect of bivalent cations on the aminopeptidase activity. Bivalent cations were assayed firstly for their effect on aminopeptidase activity and secondly for their ability to restore aminopeptidase activity after inactivation by EDTA. The aminopeptidase was preincubated with various bivalent cations: $\mathrm{CaCl}_{2}, \mathrm{CuCl}_{2}$, $\mathrm{CoCl}_{2}, \mathrm{MgCl}_{2}, \mathrm{MnCl}_{2}$ and $\mathrm{ZnCl}_{2}$ for $20 \mathrm{~min}$ at $37^{\circ} \mathrm{C}$ at final concentrations of $1 \mathrm{mM}$ in $50 \mathrm{mM}$ TEA buffer (pH 8). Its activity was then assayed at $37^{\circ} \mathrm{C}$ for 20 min using Asp-pNa as a substrate. The rate of hydrolysis of Asp-pNa in the absence of metal ion was taken as 1 . After inactivation with $1 \mathrm{mM}$ EDTA, the aminopeptidase was incubated with each cation preparation for $20 \mathrm{~min}$ at $37^{\circ} \mathrm{C}$ before the restored activity was measured as described above.

Effect of inhibitors on aminopeptidase activity. The aminopeptidase was preincubated at various concentrations of 4-(2-aminoethyl)benzenesulfonyl fluoride (Pefablock-SC), iodoacetic acid, $p$ hydroxymercuribenzoate, EDTA, o-phenanthroline, bestatin, amastatin or DTT for $20 \mathrm{~min}$ at $37^{\circ} \mathrm{C}$ in $50 \mathrm{mM}$ TEA buffer $(\mathrm{pH} 7 \cdot 5)$. Its activity was measured following the standard enzyme assay procedure and the rate of hydrolysis of Asp-pNa in the absence of any inhibitor was taken as $100 \%$.

Determination of kinetic parameters. $K_{\mathrm{m}}$ and $V_{\max }$ values for Asp$\mathrm{pNa}$ and Glu-pNa were determined from a Lineweaver-Burk plot generated from the initial reaction velocity obtained with substrate concentrations ranging from 0.5 to $15 \mathrm{mM}$ and $95 \mathrm{ng}$ purified enzyme $\mathrm{ml}^{-1}$. Each assay was carried out at $37^{\circ} \mathrm{C}$ in $50 \mathrm{mM}$ TEA ( $\mathrm{pH} 8$ ), $1 \mathrm{mM} \mathrm{MgCl}$, and the variation in $A_{410}$ was monitored continuously for $10 \mathrm{~min}$ using a 931 Uvikon spectrophotometer (Kontron Instruments).

\section{RESULTS}

\section{Aminopeptidase purification}

St-PepA was purified about 130 -fold from the cell-free extract in three chromatography steps, with an activity recovery of $2.7 \%$ as shown in Table 1 . The last purification step (Alkyl Superose) resulted in a peak which showed a single protein band upon examination by SDS-PAGE (Fig. 1) and by PAGE; after nondenaturating PAGE, the enzyme activity was detected at the same position as the protein band.

\section{Aminopeptidase properties}

The molecular mass of St-PepA was estimated to be $360 \mathrm{kDa}$ by gel filtration and $45 \mathrm{kDa}$ by SDS-PAGE. These data suggest that St-PepA is an octamer, with subunits of $45 \mathrm{kDa}$. It was active over a $\mathrm{pH}$ range of 6.5-10 with maximal hydrolysis of Asp-pNa at $\mathrm{pH} 8.5$; $75 \%$ of its activity remained at $\mathrm{pH} 10$. At $\mathrm{pH} 8$, with Asp$\mathrm{pNa}$ as a substrate, the optimum temperature was $62^{\circ} \mathrm{C}$ (Fig. 2). In fact St-PepA showed a rather high degree of thermal stability since more than $82 \%$ of the initial activity was retained after incubation at 30 or $40^{\circ} \mathrm{C}$ for $8 \mathrm{~h}$, or at 50 or $60^{\circ} \mathrm{C}$ for $2 \mathrm{~h}$ (Fig. 3).

Activity was measured in the presence of different classes of inhibitors (Table 2) and different levels of inhibition were observed. Strong inhibition (62-90\%) was observed with DTT and metal-chelating reagents such as ophenanthroline or EDTA which suggests St-PepA is a metallopeptidase. Moderate inhibition (7-34\%) was observed with inhibitors of aminopeptidases (amastatin and bestatin) and inhibitors of cysteine proteases (iodoacetic acid and $p$-hydroxymercuribenzoate). There was no inhibition at all with Pefablock, a serine protease inhibitor.

St-PepA was also inhibited by $1 \mathrm{mM} \mathrm{CuCl}_{2}$, while incubation with $1 \mathrm{mM} \mathrm{CaCl}, \mathrm{ZnCl}_{2}, \mathrm{CoCl}_{2}$ and $\mathrm{MgCl}_{2}$ resulted in an increase of activity ( $>$ twofold with $\mathrm{ZnCl}_{2}$, $\mathrm{CoCl}_{2}$ and $\mathrm{MgCl}_{2}$; Table 3). After treatment with $1 \mathrm{mM}$ EDTA, activity was only recovered with the addition of $\mathrm{Zn}^{2+}$.

\section{Substrate specificity}

St-PepA's activity was tested with several substrates (Table 4). The enzyme had three properties as follows.

Firstly, it was observed to release only acidic amino acids (Glu and Asp), Asp being preferentially released, among all the amino acid derivatives (-pNa or $-\beta-\mathrm{NA})$ tested (Arg, Phe, Lys, Pro, Asp, Glu).

Secondly, it hydrolysed di-, tri- and tetrapeptides with a $\mathrm{N}$-terminal acidic amino acid but no preference for Asp or Glu was observed. The best Asp-X dipeptide substrates were those containing an aromatic residue (Tyr or Phe) at position $\mathrm{P}_{1}^{\prime}$ (according to the nomenclature of Schechter \& Berger, 1967). St-PepA could also hydrolyse dipeptides with $\mathrm{N}$-terminal malic acid, the $\alpha$-hydroxy acid homologue of Asp; the highest rate of hydrolysis was 
Table 1. Purification of aminopeptidase St-PepA from S. thermophilus CNRZ 302

\begin{tabular}{|lccccc|}
\hline Purification step & $\begin{array}{c}\text { Total } \\
\text { protein } \\
\text { (mg) }\end{array}$ & $\begin{array}{c}\text { Total } \\
\text { activity } \\
\text { (nkat) }\end{array}$ & $\begin{array}{c}\text { Specific } \\
\text { activity } \\
\text { (nkat } \mathbf{~ m g}^{-1} \text { ) }\end{array}$ & $\begin{array}{c}\text { Yield } \\
\text { (\%) }\end{array}$ & $\begin{array}{c}\text { Purification } \\
\text { (-fold) }\end{array}$ \\
\hline Cell-free extract & 317 & 72 & $0 \cdot 23$ & 100 & 1 \\
Q-Sepharose & $10 \cdot 5$ & 50 & $4 \cdot 8$ & 69 & 21 \\
MonoQ & $1 \cdot 2$ & 21 & $17 \cdot 5$ & 29 & 77 \\
Alkyl Superose & $0 \cdot 068$ & 2 & $29 \cdot 4$ & $2 \cdot 7$ & 130 \\
\hline
\end{tabular}

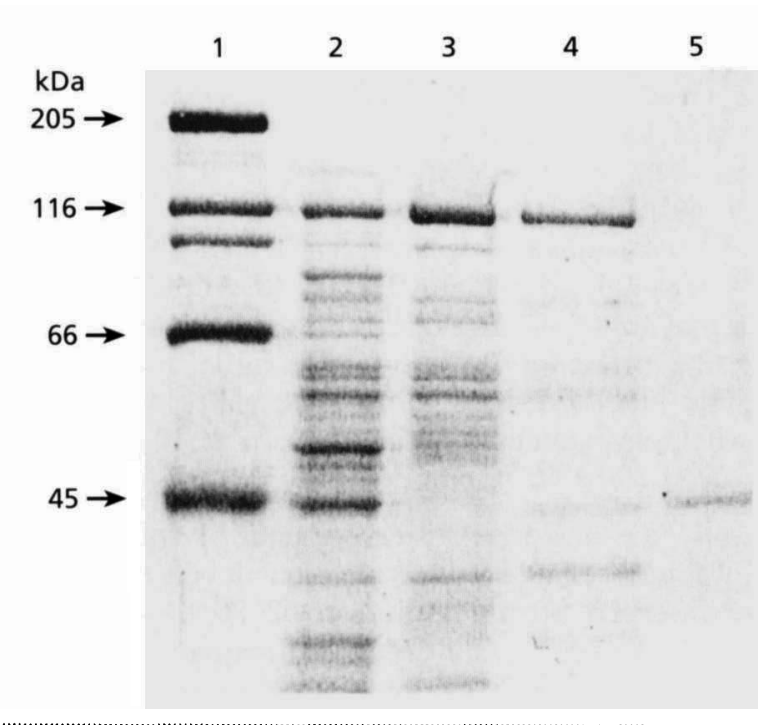

Fig. 1. SDS-PAGE of different fractions obtained during the purification of aminopeptidase St-PepA from $S$. thermophilus CNRZ 302. Lanes: 1, molecular mass standards (kDa); 2 , cell-free extract; 3 and 4, fractions from first and second anionexchange chromatography, respectively; 5, fraction from hydrophobic interaction chromatography.

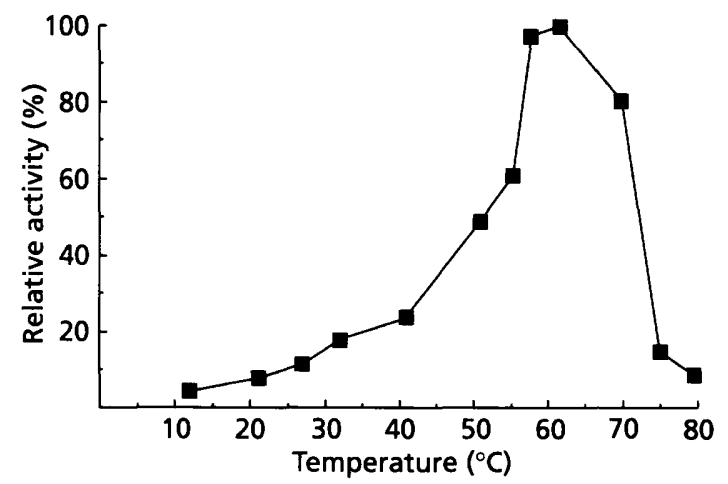

Fig. 2. Effect of temperature on the activity of St-PepA of $S$. thermophilus CNRZ 302.

measured on Mal-Tyr-OEt. Serine was released from fragment 1-4 of adrenocorticotropic hormone (SYSM) but both fragments $115-124$ of caprine $\alpha_{\mathrm{s} 1}$-casein with free or phosphorylated N-terminal serine were not

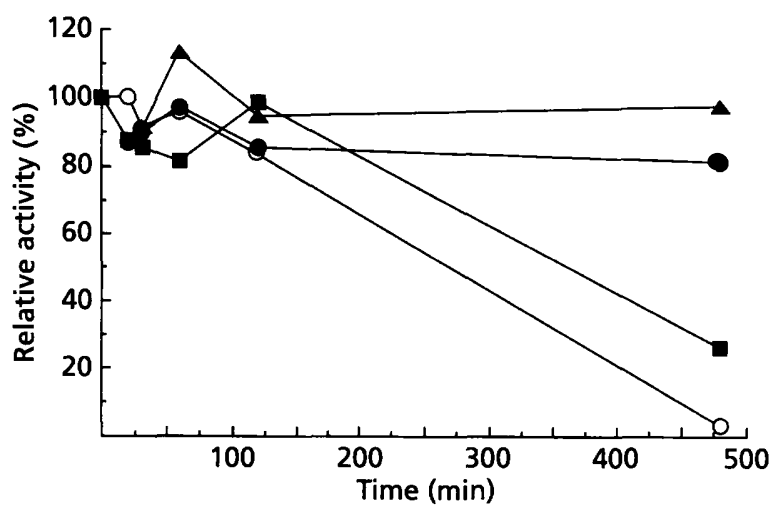

Fig. 3. Effect of temperature on the stability of St-PepA of $S$. thermophilus CNRZ 302. Samples containing $95 \mathrm{ng}$ of purified enzyme in $50 \mathrm{mM}$ TEA buffer $(\mathrm{pH} 8)$, were incubated at $30(\mathbf{\Delta})$, $40(0), 50(\square)$ and $60^{\circ} \mathrm{C}(O)$ prior to assaying at $37^{\circ} \mathrm{C}$ using Asp-pNa as substrate. Initial activity was taken as $100 \%$.

Table 2. Effect of inhibitors on St-PepA activity of S. thermophilus CNRZ 302

\begin{tabular}{|lcc|}
\hline Reagent & $\begin{array}{c}\text { Final } \\
\text { concentration } \\
(\mathbf{m M})\end{array}$ & $\begin{array}{c}\text { Inhibition } \\
\mathbf{( \% )}\end{array}$ \\
\hline Amastatin & $0 \cdot 01$ & 10 \\
Bestatin & $0 \cdot 01$ & 7 \\
Iodoacetic acid & $0 \cdot 1$ & 12 \\
p-Hydroxymercuribenzoate & 1 & 34 \\
Pefablock & 1 & 0 \\
EDTA & $0 \cdot 1$ & 62 \\
o-Phenanthroline & 1 & 91 \\
DTT & 1 & 90 \\
Control & 1 & 70 \\
\hline
\end{tabular}

hydrolysed. Dipeptides with an additional group at the $\mathrm{C}$ terminus were better substrates than those without that additional group, as demonstrated with Asp-Phe, AspPhe- $\mathrm{NH}_{2}$ and Asp-Phe-OMe (aspartame).

Finally, it was observed to hydrolyse larger peptides. NTerminal Asp was slowly released from fragment 43-58 of bovine $\alpha_{\mathrm{s} 1}$-casein (15 residues). Peptides with $\mathrm{N}$ - 
Table 3. Effect of $1 \mathrm{mM}$ bivalent cations on the aminopeptidase St-PepA activity of $S$. thermophilus CNRZ 302

\begin{tabular}{|lc|}
\hline Ion & Relative activity \\
\hline $\mathrm{Mg}^{2+}$ & $3 \cdot 7$ \\
$\mathrm{Zn}^{2+}$ & $3 \cdot 0$ \\
$\mathrm{Co}^{2+}$ & $2 \cdot 2$ \\
$\mathrm{Ca}^{2+}$ & $1 \cdot 4$ \\
$\mathrm{Mn}^{2+}$ & $0 \cdot 8$ \\
$\mathrm{Cu}^{2+}$ & $0 \cdot 6$ \\
Control & 1 \\
\hline
\end{tabular}

terminal Asp-Pro or Asp-Arg (leucokinin, angiotensin) were not hydrolysed. Liberation of serine was observed from SYSM but not from larger peptides like fragment 115-124 (10 residues) of caprine $\alpha_{\mathrm{s1}}$-casein. These results show that St-PepA preferentially degrades small $(<5$ residues) rather than large peptides.

Neither carboxypeptidase activity on carbobenzoxy-GluTyr nor endopeptidase activity on leucokinin, angiotensin I, fragment $43-58$ of bovine $\alpha_{\mathrm{s}_{1}}$-casein or fragment 115-124 of caprine $\alpha_{\mathrm{s} 1}$-casein were detected.

\section{Kinetic parameters}

Kinetic parameters were determined for the interaction of St-PepA with Asp-pNa and Glu-pNa as substrates. Lineweaver-Burk plots showed that $K_{\mathrm{m}}$ for Asp-pNa and Glu-pNa were of $0.42 \mathrm{mM}$ and $7.65 \mathrm{mM}$, respectively, thus indicating a better affinity of St-PepA for Asp-pNa. Maximal rates of hydrolysis were similar for both substrates $\left(V_{\max }\right.$ of 41.7 and $38.5 \mu \mathrm{mol} \mathrm{min}{ }^{-1} \mathrm{mg}^{-1}$ for Asp-pNa and Glu-pNa, respectively).

\section{DISCUSSION}

Our work demonstrates the existence in $S$. thermophilus CNRZ 302 of an aminopeptidase, St-PepA, specific to peptide bonds in which a $\mathrm{N}$-terminal acidic amino acid is involved.

All the aminopeptidases A described up to now are metalloenzymes and specifically liberate Glu and Asp residues. Only a few of them have been described in bacteria, the others being from human or animal origin. St-PepA differs from aminopeptidases A of human origin (Lalu et al., 1984; Mizutani et al., 1981; Nagatsu et al., 1970; Yamada et al., 1988) or of animal origin (Cheung \& Cushman, 1971; Danielson et al., 1980; Feracci et al., 1981 ; Petrovic \& Vitale, 1990; Tobe et al., 1980) in many ways, including biochemical properties such as molecular mass, multimeric structure, optimal conditions of activity and the nature of the metal ion it requires. It is closer to the bacterial aminopeptidases A which have been purified from Lactococcus lactis (Bacon et al., 1994; Niven, 1991; Exterkate \& De Veer, 1987) and Staphylococcus cbromogenes (Yoshpe-Besançon et al., 1993). All of these have a multimeric structure, are activated by $\mathrm{Zn}^{2+}$ or $\mathrm{Co}^{2+}$ and are characterized by a rather alkaline optimal $\mathrm{pH}$ and a high optimal temperature (about $60^{\circ} \mathrm{C}$ ). In addition, StPepA has other properties in common with lactococcal aminopeptidases A. Firstly, $\mathrm{Zn}^{2+}$ can restore the activity of St-PepA and PepA from L. lactis HP (Exterkate \& De

Table 4. Substrate specificity of St-PepA from S. thermophilus CNRZ 302

The rate of hydrolysis of Asp-Tyr was taken as $100 \%$. OMe and -OEt, methyl ester and ethyl ester, respectively.

\begin{tabular}{|lccc|}
\hline Substrate & $\begin{array}{c}\text { Relative } \\
\text { activity } \\
\mathbf{( \% )}\end{array}$ & \multicolumn{1}{c|}{ Substrate } & $\begin{array}{c}\text { Relative } \\
\text { activity } \\
\text { (\%) }\end{array}$ \\
\hline Asp-pNa & 15 & Glu-Val-Phe & 139 \\
Glu-pNa & 5 & Ser-Tyr-Ser-Met & 70 \\
Asp- $\beta$-Na & 6 & Bovine $\alpha_{\text {s1 }}$-casein & 4 \\
Glu- $\beta$-Na & 0 & (fragment 43-58) & \\
Asp-Gln & 37 & (DIGSESTEDQAMEDIK) & \\
Asp-Lys & 13 & P P & 0 \\
Glu-Lys & 34 & Angiotensin I & \\
Glu-Ser & 100 & (DRVYIHPFHL) & \\
Asp-Phe & 52 & Leucokinin & 0 \\
Asp-Phe-OMe & 120 & (DPAFNSWG) & \\
Asp-Phe-NH ${ }_{2}$ & 100 & Caprine $\alpha_{\text {s1 }}$-casein & \\
Asp-Tyr & 100 & (fragment $115-124)$ & \\
Mal-Tyr-OEt & 266 & (SAEEQLHSMK) & \\
Asp-Tyr-Met & 100 & P & \\
Asp-Tyr-Met-Gly & 94 & & \\
\hline
\end{tabular}


Veer, 1987) after treatment with EDTA and, secondly, StPepA and PepA from L. lactis HP (Exterkate \& De Veer, 1987) and AM2 (Bacon et al., 1994) exhibit especially good temperature stability.

St-PepA has a high substrate specificity towards acidic amino acid residues at the $\mathrm{N}$ terminus of peptides but it can also release serine. St-PepA shares with the aminopeptidase A from $S$. chromogenes (Yoshpe-Besançon $e t$ al., 1993) the ability to liberate $\mathrm{N}$-terminal malic acid, the $\alpha$ hydroxy acid homologue of Asp. Thus, streptococcal and staphylococcal aminopeptidases A show no strict requirement for a free $\alpha$-amino group, contrary to the aminopeptidase A from $L$. lactis subsp. cremoris AM2 (Bacon et al., 1994).

The specificity of St-PepA and especially its capacity to liberate Glu is interesting for two reasons.

Firstly, because St-PepA is most probably important in the nitrogen metabolism of $S$. thermophilus. S. thermopbilus generally does not possess a substantial extracellular proteolytic activity (Shahbal et al., 1991) and peptides from caseins must be released by the cell-wall-associated proteinase of lactobacilli and by the rennet, in the case of cheese manufacturing. These peptides are rich in Asp and Glu as caseins are and could be transported into the cell; Desmazeaud \& Hermier (1972) indeed suggested that $S$. thermopbilus possesses an oligopeptide transport system. Moreover Glu is essential for S. thermophilus growth (Bracquart et al., 1978) and none of the peptidases of $S$. thermophilus so far characterized could release acidic amino acids very efficiently (Midwinter \& Pritchard, 1994; Rul, 1994; Tsakalidou \& Kalantsopoulos, 1992).

Secondly, because St-PepA could contribute to flavour development during cheese ripening by liberating free amino acids. Glutamic acid is the major free amino acid in Swiss-type cheese and Biede \& Hammond (1979) suggested that it can play a role in cheese flavour because of its broth taste and its flavour-enhancing properties. Furthermore, it has been shown recently that Glu can contribute to lowering the bitterness of a trypsic hydrolysate of casein (Warmke \& Belitz, 1993). St-PepA could also participate to the decrease of bitterness by hydrolysing, with other peptidases we have described (Rul, 1994), hydrophobic peptides responsible for bitterness.

Three aminopeptidases have now been purified from $S$. thermophilus: St-PepA and two general aminopeptidases, St-PepC and St-PepN. Biochemical studies and sequence data supported the evidence of a striking resemblance between the streptococcal aminopeptidases and PepC, PepN and PepA from lactococci. The aminopeptidases isolated from the two species indeed have similar biochemical properties and substrate specificities. Moreover, the $\mathrm{N}$ terminus sequences we obtained from the purified proteins St-PepN (Rul et al., 1994) and St-PepA (data not shown) are $67 \%$ (19 residues) and $77 \%$ (13 residues) homologous, respectively, to the sequences of the corresponding lactococcal aminopeptidases PepN (Tan \&
Konings, 1990) and PepA (F. Mülholland, personal communication). Finally, the gene encoding St-PepC was sequenced by our group (Chapot-Chartier et al., 1994) and was found to be $82 \%$ similar to the gene $p e p C$ encoding PepC from L. lactis.

\section{ACKNOWLEDGEMENTS}

This work was supported by the French Ministry of Research and Technology (programme Aliment 2002, contract no. 90T0927). We thank P. Anglade and G. Brignon for the Nterminal sequencing of peptides.

\section{REFERENCES}

Bacon, C. L., Jennings, P. V., Fhaolain, I. N. \& O'Cuinn, G. (1994). Purification and characterization of an aminopeptidase $A$ from cytoplasm of Lactococcus lactis subsp. cremoris AM2. Int Dairy J 4, 503-519.

Biede, S. L. \& Hammond, E. G. (1979). Swiss cheese flavor. II. Organoleptic analysis. J Dairy Sci 62, 238-248.

Bracquart, P., Lorient, D. \& Alais, C. (1978). Effet des acides aminés sur la croissance de Streptococcus thermophilus. II: Etude sur cinq souches. Milchwissenschaft 33, 341-344.

Bradford, M. M. (1976). A rapid and sensitive method for quantitation of microgram quantities of protein utilizing the principle of protein-dye binding. Anal Biocbem 72, 248-254.

Chapot-Chartier, M. P., Rul, F., Nardi, M. \& Gripon, J. C. (1994). Gene cloning and characterization of PepC, a cysteine aminopeptidase from Streptococcus thermophilus, with sequence similarity to the eucaryotic bleomycin hydrolase. Eur J Biochem 224, 497-506.

Cheung, H. S. \& Cushman, D. W. (1971). A soluble aspartate aminopeptidase from dog kidney. Biochim Biophys Acta 242, 190-193.

Danielson, E. M., Noren, O., Sjöström, H., Ingram, J. \& Kenny, A. (1980). Proteins of the kidney microvillar membrane. Aspartate aminopeptidase: purification by immunoadsorbent chromatography and properties of the detergent and proteinase solubilized forms. Biochem J 189, 591-603.

Desmazeaud, M. J. (1974). Propriétés générales et spécificité d'action d'une endopeptidase neutre intracellulaire de Streptococcus thermophilus. Biocbimie 56, 1173-1181.

Desmazeaud, M. J. \& Hermier, J. H. (1972). Isolement et détermination de la composition qualitative de peptides issus de la caséine, stimulant la croissance de Streptococcus thermophilus. Eur J Biochem 28, 190-198.

Exterkate, F. A. \& De Veer, G. J. C. M. (1987). Purification and some properties of a membrane-bound aminopeptidase A from Streptococcus cremoris. Appl Environ Microbiol 53, 577-583.

Feracci, H., Benajiba, A., Gorvel, J. P., Doumeng, C. \& Maroux, S. (1981). Enzymatic and immunological properties of the protease form of aminopeptidases $\mathrm{N}$ and $\mathrm{A}$ from pig and rabbit intestinal brush border. Biochim Biophys Acta 658, 148-157.

Kok, J. (1990). Genetics of the proteolytic system of lactic acid bacteria. FEMS Microbiol Rev 87, 15-41.

Laan, H., Smid, E. J., Tan, P. S. T. \& Konings, W. N. (1989). Enzymes involved in the degradation and utilization of casein in Lactococcus lactis. Neth Milk Dairy J 43, 327-345.

Laemmli, U. K. (1970). Cleavage of the structural proteins during the assembly of the head of bacteriophage T4. Nature 227, 680-685.

Lalu, K., Lampelo, S., Nummelin-Kortelainen, M. \& VanhaPerttula, T. (1984). Purification and partial characterization of 
aminopeptidase $A$ from the serum of pregnant and non-pregnant women. Biochim Biophys Acta 789, 324-333.

Law, B. A. \& Kolstad, D. J. (1983). Proteolytic systems in lactic acid bacteria. Antonie Leeuwenboek 49, 225-245.

Meyer, J. \& Jordi, R. (1987). Purification and characterization of Xprolyl-dipeptidyl-aminopeptidase from Lactobacillus lactis and Streptococcus thermophilus. J Dairy Sci 70, 738-745.

Midwinter, R. G. \& Pritchard, G. G. (1994). Aminopeptidase N from Streptococcus salivarius subsp. thermophilus NCDO 573: purification and properties. J Appl Bacteriol 77, 288-295.

Mizutani, S., Okano, K., Hasegawa, E., Salura, H. \& Yamada, M. (1981). Aminopeptidase A in human placenta. Biochim Biopbys Acta 678, 168-170.

Monnet, V., Chapot-Chartier, M.-P. \& Gripon, J.-C. (1993). Les peptidases des lactocoques. Lait 73, 97-108.

Nagatsu, I., Nagatsu, T., Yamamoto, T., Glenner, G. G., \& Mehl, J. W. (1970). Purification of aminopeptidase $A$ in human serum and degradation of angiotensin II by the purified enzyme. Biocbim Biophys Acta 198, 255-270.

Niven, G. W. (1991). Purification and characterization of aminopeptidase A from Lactococcus lactis subsp. lactis NCDO 712. J Gen Microbiol 137, 1207-1212.

Petrovic, S. \& Vitale, L. (1990). Purification and properties of glutamyl aminopeptidase from chicken egg-white. Comp Biochem Pbysiol 95B, 589-595.

Rabier, D. \& Desmazeaud, M. J. (1973). Inventaire des différentes activités peptidasiques intracellulaires de Streptococcus thermophilus. Biochimie 55, 389-404.

Rul, F. (1994). Contribution à l'étude du système peptidasique de Streptococcus thermophilus CNRZ 302. PhD thesis, University of Caen, France.

Rul, F., Monnet, V. \& Gripon, J. C. (1994). Purification and characterization of a general aminopeptidase (St-PepN) from Streptococcus salivarius ssp. thermopbilus CNRZ 302. J Dairy Sci 77, 2880-2889.

Schechter, K. \& Berger, B. (1967). On the size of the active site of proteases. I. Papaïn. Biochem Biophys Res Commun 27, 157-162.
Shahbal, S., Hemme, D. \& Desmazeaud, M. (1991). High cell wallassociated proteinase activity of some Streptococcus thermophilus strains (H-strains) correlated with high acidification rate in milk. Lait 71, 351-357.

Tan, P. S. T. \& Konings, W. N. (1990). Purification and characterization of an aminopeptidase from Lactococcus lactis subsp. cremoris Wg2. Appl Environ Microbiol 56, 526-532.

Tan, P. S. T., Poolman, B. \& Konings, W. N. (1993). Proteolytic enzymes of Lactococcus lactis. J Dairy Res 60, 269-286.

Thomas, T. D. \& Pritchard, G. G. (1987). Proteolytic enzymes of dairy starter cultures. FEMS Microbiol Rev 46, 245-286.

Tobe, H., Kojima, F., Aoyagi, T. \& Umezawa, H. (1980). Purification by affinity chromatography using amastatin and properties of aminopeptidase A from pig kidney. Biocbim Biophys Acta 613, 459-468.

Tsakalidou, E. \& Kalantsopoulos, G. (1992). Purification and partial characterization of an intracellular aminopeptidase from Streptococcus salivarius subsp. thermophilus. J Appl Bacteriol 72, 227-232.

Warmke, R. \& Belitz, H. D. (1993). Influence of glutamic acid on the bitter taste of various compounds. Z. Lebensm Untersuch Forsch 197, 132-133.

Yamada, R., Mizutani, S., Kurauchi, O., Okano, K., Imaizumi, H., Narita, O. \& Tomoda, Y. (1988). Purification and characterization of human placental aminopeptidase A. Enzyme 40, 223-230.

Yoshpe-Besançon, I., Auriol, D., Paul, F., Monsan, P., Gripon, J.-C. \& Ribadeau-Dumas, B. (1993). Purification and characterization of an aminopeptidase A from Staphylococcus chromogenes and its use for the synthesis of amino-acid derivatives and dipeptides. Eur $J$ Biochem 211, 105-110.

Zevaco, C., Monnet, V., \& Gripon, J. C. (1990). Intracellular Xprolyl-dipeptidyl peptidase from Lactococcus lactis ssp. lactis: purification and properties. $J$ Appl Bacteriol 68, 357-366.

Received 16 March 1995; revised 5 May 1995; accepted 15 May 1995. 